\title{
PENGEMBANGAN APLIKASI ENGLISH GAME FOR HEARING IMPAIRED STUDENTS BERBASIS KOMPUTER
}

\author{
Sri Ariyanti Sabiku ${ }^{1}$ \\ Program Studi Teknik Informatika, Politeknik \\ Gorontalo \\ Bone Bolango, Gorontalo, Indonesia \\ riantisabiku@poligon.ac.id
}

\begin{abstract}
ABSTRAK-Penelitian ini bertujuan: (1)mengembangkan Aplikasi English Gamefor Hearing Impaired StudentsBerbasis Komputer, (2)mengetahui kelayakan desain aplikasi berdasarkan penilaian ahli materi, ahli media, dan peserta didik tunarungu, (3)mengetahui penguasaan kosakata Bahasa Inggris peserta didik tunarungu dengan menggunakan mediapembelajaran ini.Jenis penelitian ini adalah Penelitian dan Pengembangan atau dikenal Research and Development (R\&D) dengan tahapan sebagai berikut: Studi Pendahuluan(Analisis),PerencanaanDesain,Pengemb anganDesain,Validasi Ahli, Revisi, Uji Coba Pengguna. Subjek uji coba penelitian berjumlah 9 orang yang terdiri dari 6 orang perempuan dan 3 orang laki-laki di tingkat SMP-LB Kelas Tipe BTunarungu SLB Negeri Kota Gorontalo. Teknik pengumpulan data menggunakan observasi, wawancara, dokumentasi, angket, dan tes. Data yang dikumpulkan kemudian dianalisis menggunakan teknik analisis kualitatif deskriptifdan teknik analisis kuantitatifdeskriptif.Hasil penelitian menunjukan bahwaAplikasi English Game for Hearing Impaired Students Berbasis Komputer sebagai Media Pembelajaran dalam Mengenalkan Kosakata Bahasa Inggris dengan tingkat kelayakan berdasarkan penilaian ahli media sebesar $88.07 \%$ atau dapat dikonversi sama dengan 4.403 termasuk kategori sangat layak, penilaian ahli materi sebesar $90 \%$ atau dapat dikonversi sama dengan 4.5 termasuk kategori sangat layak. Kemudian, hasil uji coba pengguna mengenai tanggapan tingkat kelayakan media sebesar 90,67\% atau dapat dikonversi sebesar 4.533 termasuk kategori sangat layak. Penelitian inijuga membuktikan adanya peningkatan penguasaan kosakata Bahasa Inggris yang tergambarkan melalui perbandingan masing-masing skor perolehan tes kosakata peserta didik yang menggunakan aplikasi dibandingkan tanpa menggunakan aplikasi.Dengan demikian, dapat disimpulkanaplikasi inilayak digunakan sebagai media pembelajaran dalam mengenalkan kosakata Bahasa Inggris di SLB Negeri Kota Gorontalo.
\end{abstract}

Kata Kunci: English Game, Hearing-Impaired Students, Komputer, Media Pembelajaran, Pengenalan Kosakata

\section{PENDAHULUAN}

Bahasa merupakan alat komunikasi antar manusia untuk dapat mengekspresikan suatu gagasan dan perasaanmasingmasing individu. Selain itu juga bahasa mempunyai peranan utama yang sangat penting dalam perkembangan sosial, emosional dan intelektual serta sebagai penunjang keberhasilan untuk mempelajari keseluruhan bidang studi dari seorang peserta didik.

Di Negera Indonesia, Bahasa Inggris sebagai bahasa asing yang berperan penting dalam hal komunikasi antar bangsa terutama untuk membantu meningkatkan daya saing bangsa. Bahkanpada setiap jenjang pendidikan, Bahasa Inggris merupakan mata pelajaran yang dicantumkan dalam kurikulum di Indonesia. Pada tingkat pendidikan bagi anakanak berkebutuhan khusus sepertiSekolah Luar Biasa, Bahasa Inggris diajarkan dengan tujuan untuk membekali peserta didik agar dapat memiliki kompetensi komunikasi baik secara lisan dan tulisan sesuai dengan kaidah penggunaan bahasa Inggris oleh penuturnya.

Sekolah Menengah Pertama Luar Biasa (SMPLB) pada Bagian B Tunarungu menekankan pembelajaran bahasa Inggris pada empat tingkat literasi seperti performative, functional, informational, dan epistemic.Untuk dapat menguasai empat tingkat literasi tersebut maka tentu memerlukan pengetahuan kosakata yang memadai. Karena kosakata merupakan salah satu unsur kebahasaan dalam menunjang beberapa keterampilan lainnya pada proses pembelajaran Bahasa Inggris.

Disisi lain terwujudnya tujuan ini akan sulit tercapai bila dihadapkan pada permasalahan-permasalahan yang muncul dan sering kali ditemui. Kurangnya motivasi belajar bahasa Inggris dan fasilitas penunjang pembelajaran, keterbatasan dari seorang guru untukmendesain materibahkan media pembelajaran menarik yang dapat berimplikasi terhadaptinggi ataurendahnya tingkat penguasaan kosakata Bahasa Inggris dari seorang peserta didik.

Somantri (2012:97) menyatakan dalam bukunya yang membahas Psikologi Anak Luar Biasa bahwa

"Kerendahan tingkat intelegensi anak tunarungu bukan berasal dari hambatan intelektualnya yang rendah melainkan secara umum karena intelegensinya tidak mendapat kesempatan untuk berkembang. Pemberian bimbingan yang teratur terutama dalam kecakapan berbahasa akan dapat membantu perkembangan intelegensi anak tunarungu."

Berdasarkan pendapat ini maka peran lingkungan dapat diasumsikan sangat berpengaruh terhadap perkembangan seorang peserta didik tunarungu.Keterlibatan pada lingkungan baik dirumah bersama keluarga, di masyarakat, di sekolah dan lain-lain akan sangat menentukan kesempatan belajar bagi seorang anak tunarungu untuk mengembangkan kemampuan intelegensinya dan keterampilan berkomunikasinya.

Salah satu pendapat lain sepertiCruickshank yang jugadikemukakan oleh Somantri (2012:97) yakni:
“...Anak-anak tunarungu sering memperlihatkan keterlambatan dalam 
belajar dan kadang-kadang tampak terbelakang. keadaan ini tidak hanya disebabkan oleh derajat gangguan pendengaran yang dialami anak tetapi juga tergantung pada potensi kecerdasan yang dimiliki, rangsangan mental, serta dorongan dari lingkungan luar yang memberikan kesempatan bagi anak untuk mengembangkan kecerdasan itu."

Dengan demikian dapat dilihat bahwa untuk tetap meningkatkan kecerdasan anak tunarungu diperlukan strategi yang terbaiknya dalam upaya mendidik anak tersebut sejak usia dini.Strategi tersebut bisa dalam berbagai hal misalnya strategi menciptakan suasana pembelajaran yang kondusif dan nyaman bagi peserta didik menggali kecerdasan mereka. Guru dalam hal ini memiliki peran sentral menentukan keberhasilan proses pendidikan bagi peserta didik tunarungu sehingga mereka mampu menerima pembelajaran secara maksimal.

Di era globalisasi ini, kehidupan manusia tidak terlepas dari penggunaan teknologi informasi dan komunikasi. Hal tersebut dibuktikan dengan adanyaupaya penggunaan teknologi informasi dan komunikasi di berbagai bidang terlebih dalam bidang pendidikan. Seiring dengan berkembangnya zaman, pemanfaatan teknologi informasi dan komunikasi begitu marak terlihatmelalui terciptanya berbagai inovasi produk yang dihasilkan untuk menunjang proses pembelajaran. Upaya pengaplikasian berbagai media pembelajaran berbasis teknologi seperti radio, televisi, tape recorder, video, komputer, dan lain-lain diintegrasikan ke dalam proses belajar mengajar dengan maksud agar mampu menunjangtercapainya keberhasilan proses pembelajaran yang telah dirancang dan disusun sebelumnya oleh pendidik/guru.

Keberhasilan proses pembelajaran ditentukan dengan bagaimana pemilihan dan penggunaan media ajar sesuai dengan tingkat kebutuhan dan kondisi permasalahanan peserta didik. Penggunaan media akan mampu menunjang guru dan peserta didikuntuk melakukan proses pembelajaran. Sesuai denganpengamatan yang dilakukan oleh tim peneliti bahwa pada umumnya pembelajaran Bahasa Inggris saat ini bagi anak tunarungu masih bersifatconventional seperti bantuan gestures, lip reading, facial expression, dan bahkan kurang up-to-date menggunakan media yangdapat membangun suasana menarik dan berbeda dalam proses pembelajarannya. Menurut hasil penelitian terdahulu yang dilakukan oleh beberapa peneliti, salah satunya Harahap \& Sari di tahun 2016 mengenai media pembelajaran Bahasa Inggris dengan berbasis Kinnect mampu menciptakan suasana belajar yang baik yang merangsang kemampuan motorik anak dalam belajar.

Berdasarkan uraian ini maka tim peneliti ingin melakukan penelitian sehubungan dengan "PengembanganAplikasi English Gamefor Hearing Impaired Students Berbasis Komputer sebagai Media Pembelajaran untukmengenalkanKosakata Bahasa Inggris di SLB Negeri Kota Gorontalo. Penelitian ini ditujukan untukmenggambarkan bagaimana tahapan pengembangan media pembelajaran untuk mengenalkan kosakata Bahasa Inggris di kelas tunarungu,mengetahui kelayakan desain media ini serta mengetahui penguasaan kosakata Bahasa Inggris peserta didik tunarungu denganatau tanpa menggunakan media ini.

\section{II.METODE PENELITIAN}

\subsection{Jenis dan Metode Penelitian}

Jenis penelitian ini adalah Penelitian dan Pengembangan atau disebut dengan istilah lainnya Research and Development ( $R \&$ \& ). Sugiyono (2012:494) mengatakan "Metode penelitian pengembangan digunakan untuk mengembangkan dan menguji produk tertentu." Dalam strategi ini, penelitian dilakukan dalam dua tahap yakni pertama melalui metode kualitatif sehingga dapat diperoleh rancangan produk, dan penelitian tahap kedua dengan metode kuantitatif untuk menguji keefektifan dari produk yang dirancang. Berikut tahapan-tahapan penelitian yang ditempuh oleh tim peneliti:

\subsubsection{Studi Pendahuluan (Analisis)}

Studi pendahuluan merupakan tahap awal dimana tim peneliti mengumpulkan data melalui observasi lapangan, wawancara, pendokumentasian informasi dan literatur yang berhubungan dengan permasalahan yang diteliti. Hal ini ditujukan untuk memperoleh informasi secara detil dan akurat terkait permasalahan yang terjadi. Instrumen yang digunakan dalam studi pendahuluan ini berupa lembar observasi, lembar wawancara untuk menelusuri permasalahan pembelajaran dan kebutuhan pembelajaran yang diharapkan.

Adapun tahap analisis ini meliputi: (a) menganalisis kompetensi yang diharapkan kepada peserta didik tunarungu dalam pembelajaran Bahasa Inggris, (b)menganalisis karakteristik peserta didik tunarungu seperti analisis kapasitas belajar, pengetahuan, keterampilan, sikap yang telah dimiliki oleh peserta didik tunarungu, beserta beberapa aspek terkait lainnya,(c)Menganalisis topik materi/aspek sesuai dengan kebutuhan kompetensi yang diharapkan kepada peserta didik tunarungu, (d) Membuat dokumen perencanaan sesuai dengan hasil analisis sebelumnya seperti perencanaan materi (penentuan sumber materi yang akan diambil) dan hal-hal yang diperlukan dalam menyusun produk media pembelajaran melalui brainstorming (diskusi dengan guru mata pelajaran Bahasa Inggris dan teman sejawat).

\subsubsection{Perencanaan Desain}

Proses perencanaan desain ini adalah tahap merancang produk yang akan dihasilkan dan bagaimana prosespengembangannya. Adapun tahapan-tahapan yang dilalui dalam perencanaan desain sebagai berikut:

- Melakukan perancangan media pembelajaran dengan mengacu kepada beberapa aspek penting sebagai berikut: (a) untuk siapa media pembelajaran ini dirancang, (b) kemampuan apa yang ingin dicapai dalam pembelajaran ini, (c) bagaimana topik/materi pelajaran ini dapat dipelajari dengan baik oleh peserta didik tunarungu, (d) bagaimana menentukan tingkat penguasaan pelajaran ini sudah dapat dicapai oleh peserta didik tunarungu.

- Membuat storyboards.

\subsubsection{Pengembangan Desain}

Tahap pengembangan desain meliputi proses pembuatan desain game yang meliputi hal-hal sebagai berikut: (a) Menyiapkan topik atau bahan materi Bahasa Inggris untuk media pembelajaran berbasis komputer (pengambilan gambar-gambar, penyusunan kosakata sesuai 
dengan gambar, dan kerangka soal yang berkaitan dengan topik/materi yang ingin diajarkan, (b)Menentukan seperti apa model game, warna dan jenis tulisan, background, (c)Membuat media pembelajaran dengan menggunakan aplikasi dan alat yang dibutuhkan dalam merancang media ini pembelajaran ini.

\subsubsection{Validasi Ahli}

Dalam tahap ini, tim peneliti melakukan proses validasi ahli media dan ahli materi mengenai media yang telah dikembangkan sebelumnya. Validasi ini melihat sejauh mana komentar dan saran/perbaikan kekurangan dan kelebihan hasil rancangan yang telah dikembangkan oleh tim peneliti sebelum dilakukannya uji coba produk kepada pengguna.

\subsubsection{Revisi Desain}

Tahap ini dilakukan untuk memperbaiki produk yang telah dikembangkan. Acuan perbaikan produk diambil berdasarkan penilaian ahli media dan ahli materi.Setelah direvisi, maka produk kemudian diujicobakan kepada pengguna.

\subsubsection{Ujicoba Pengguna}

Tahap akhiradalah proses dimana tim peneliti melakukan ujicoba pengguna yang dalam hal ini adalah peserta didik tunarungu sebagai sasaran produk. Tujuan dari dilakukannya ujicoba pengguna untuk mengetahui hasil dari penggunaan produk yang telah direvisi. Setelah dilakukannya ujicoba pengguna, maka keseluruhan responden mengisi angket yang diharapkan dapat memberikan komentar baik koreksi maupun saran/masukan terkait produk yang diujicobakan untuk kemudian dianalisis sebagai acuanperbaikan merevisi produk akhir.Jika tidak memungkinkan untuk dilakukan perbaikan, maka hal tersebut menjadi masukan pada penelitian yang selanjutnya.

\subsection{Lokasi Penelitian}

Penelitian dilaksanakan di SLB Negeri Kota Gorontalo yang berlokasi di Jalan Beringin, Kelurahan Tuladenggi, Kecamatan Dungingi, Provinsi Gorontalo.

\subsection{Subjek dan Objek Penelitian}

Subjek penelitian adalah peserta didiktingkat SMP-LB Tipe B Tunarungu Tahun Ajaran 2016/2017. Subjek yang diteliti sebanyak 9 orang terdiri dari 6 orang perempuan dan 3 orang laki-laki. Subjek penelitian dipilih melalui teknik purposive sampling dengan tujuan yang pertama adalah subjek ini belum pernah memperoleh pengembangan dan penerapan media pembelajaran dalam bentuk Aplikasi English Game for Hearing Impaired Studentsberbasiskomputer.

Sedangkan Objek Penelitian dalam penelitian ini adalah media pembelajaran yakni "Aplikasi English Game for Hearing Impaired Students Berbasis Komputer" yang didukung oleh software Macromedia Flash 8.

\subsection{Teknik Pengumpulan Data}

\subsubsection{Observasi}

Teknik pengumpulan data menggunakan observasi dengan tipe participant observer. Menurut Sugiyono (2012:311) terdapat 4 kategori participant observer yakni passive participation, moderate participation, active participation dan complete participation. Dalam penelitian ini, tim peneliti mengunakan jenis active participation dimana tim penelitiikut melakukan apa yang dilakukan oleh narasumber yakni guru dan peserta didik namun belum sepenuhnya lengkap. Observasi ini dilakukan terhadap pihak sekolah, guru, peserta didik, dan situasi proses pembelajaran saat penerapan aplikasi.

\subsubsection{Interview}

Teknik pengumpulan datamenggunakan jenis wawancara semiterstruktur atau dikenal dengan semi structure interview. Teknik wawancara ini bertujuan untuk menemukan permasalahan dengan lebih terbuka. Pihak yang diajak wawancara dimintai ide dan pendapat terkait permasalahan yang sedang ditelusuri atau diteliti.

\subsubsection{Dokumentasi}

Teknik pengumpulan data menggunakan dokumentasi beberapa data penting yang dapat menunjang atau melengkapi data observasi dan wawancara dalam penelitian ini. Data ini berupa dokumen foto, tulisan atau cacatan perkembangan peserta didik tunarungu khususnya dalam pembelajaran Bahasa Inggris.

\subsubsection{Angket dan Tes}

Teknik pengumpulan data melalui angket dan tes ini ditujukan sebagai feedback atau balikan untuk mengetahui hasil dari proses pengembangan dan penerapan aplikasi ini, kemampuan dan minat peserta didik sebelum, selama dan sesudah proses pembelajaran serta kelemahan maupun kelebihan dari pengembangan dan penerapan aplikasi tersebut. Instrumen angket ini disediakan oleh tim peneliti untuk ahli media, dan ahli materi, serta peserta didik tunarungu. Angket yang digunakan diadaptasi dari Dewi (2012) dan Anandhita (2014).

\subsection{Teknik Analisis Data}

Data yang diperoleh dalam penelitian ini terdiri dari dua bagian yakni data kualitatif dan data kuantitatif. Untuk menganalisis data penelitian ini, tim peneliti melakukan beberapa teknik analisis sebagai berikut:

\subsubsection{Analisis kualitatifdeskriptif}

Teknik analisis kualitatif deskriptif digunakan oleh tim peneliti untuk mengolah data-data hasil reviewpara ahli media, ahli materi, danpeserta didik tunarunguterkait produk pembelajaran. Teknik ini dilakukan dengan menganalisis data hasil pengelompokan informasi-informasi dari data kualitatif seperti masukan, tanggapan, saran perbaikan, dan kritik yang sudah disediakan dalam angket. Selain itu, teknik analisis kualitatif deskriptif dilakukan untuk menganalisis data hasil evaluasi penguasaan kosakata peserta didik tunarungu dengan dan tanpa diterapkannya produk berupa aplikasi game yang telah dikembangan oleh tim peneliti. Hasil- hasil yang diperoleh dari analisis data tersebut digunakan sebagai acuan dalam perbaikan produk media pembelajaran. 


\subsubsection{Analisis kuantitatifdeskriptif}

Untuk melengkapi hasil analisis kualitatif, maka diperlukan adanya pengumpulan dan analisis data secara kuantitatif. Tujuan analisis data adalah untuk mengetahui bagaimana aplikasi yang dikembangkan memenuhi kriteriakriteria yang telah ditentukan. Analisis kuantitatif deskriptif dianggap tepat untuk memenuhi tujuan ini. Analisis yang digunakan sesuai panduan yang diberikan oleh Sugiono dalam bukunya yang berjudul Metode Penelitian Kombinasi,tahun 2012.

Setelah diadakan pengembangan media, validasi, revisi, dan uji coba, tahap selanjutnya yaitu menganalisis data.Data yang berupa jawaban angket bagi ahli media, ahli materi, dan subjek uji coba diolah dalam bentuk angka.Proses pengolahan data angket sesuai dengan yang disarankan oleh Sugiono (2011:138).

Data dikumpulkan dalam bentuk angket yang berisi kriteria yang ingin diukur. Setiap jawaban dari kriteria diberikan dalam skala Likert dengan range: Sangat Tidak Setuju, Tidak Setuju, Ragu-Ragu, Setuju, Sangat Setuju. Untuk kepentingan analisis kuantitatif maka setiap pilihan diberikan skor, sesuai dengan tabel berikut ini:

Tabel1. Kriteria Penilaian

\begin{tabular}{|l|l|}
\hline Pilihan & Skor \\
\hline Sangat Tidak Setuju (STS) & 1 \\
\hline Tidak Setuju (TS) & 2 \\
\hline Ragu-Ragu R & 3 \\
\hline Setuju (S) & 4 \\
\hline Sangat Setuju (SS) & 5 \\
\hline
\end{tabular}

Data yang dikumpulkan melalui angket adalah berupa data interval yang perlu direpresentasikan dalam kontinuum skala yang ditentukan. Untuk itu perlu adanya perhitungan kriterium (skor ideal) dari angket. Kriterium bisa dihitung dengan rumus berikut:

Kriterium $=$ Skor Max $\times$ Jumlah Partisipan

Misalnya skor maksimum dari jawaban adalah 5 dan terdapat 20 partisipan maka kriterium $=5 \times 20=100$. Setelah kriterium diketahui, maka langkah selanjutnya adalah menghitung jumlah skor yang diperoleh untuk setiap kriteria yang ada di angket:

$$
\text { Skor }=\text { jumlah }_{S T S} \times 1+\text { jumlah }_{T S} \times 2+\text { jumlah }_{R} \times 3
$$$$
+ \text { jumlah }_{S} \times 4+\text { jumlah }_{S S} \times 5
$$

Sebagai contoh yang dilakukan dalam penelitian ini misalnya, jika dari 20 partisipan ada 15 orang yang menjawab setuju (S) dan 5 orang menjawab sangat setuju (SS), maka:

skor $=0 \times 1+0 \times 2+0 \times 3+15 \times 4+5 \times 5=85$

Dengan demikian, tingkat persetujuan dari partisipan adalah $\frac{85}{100}=85 \%$. Ini bisa digambarkan secara kontinum sebagai berikut:

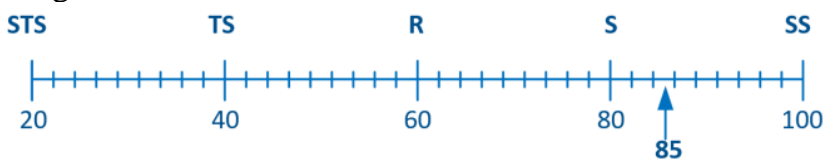

Metode yang telah dijelaskan dalam penelitian ini baik digunakan oleh tim peneliti untuk mengetahui persentasi dan letak jawaban pada skala kontinum. Akan tetapi, sesuai dengan rumusan masalah penelitian, dibutuhkan sebuah metode untuk mengetahui kelayakan aplikasi sesuai dengan penilaian responden. Hal ini bisa dilakukan dengan mengkonversi rata-rata jawaban responden dari bentuk kuantitatif ke kualitatif. Proses konversi nilai ini diadopsi dari Sukardjo (2005). Berikut ini dijelaskan konversi data kuantitatif ke kualitatif menggunakan 5 skala Likert:
Tabel 2. Konversi Data Kuantitatif ke Kualitatif

\begin{tabular}{|c|c|c|}
\hline \multicolumn{2}{|l|}{ Interval Skor } & \multirow[t]{2}{*}{ Kategori } \\
\hline Rumus & $\begin{array}{l}\text { Hasil } \\
\text { Perhitungan/Kriteria }\end{array}$ & \\
\hline $\begin{array}{l}x \\
>X_{i}+1.80 S b_{i}\end{array}$ & $x>4.21$ & $\begin{array}{l}\text { Sangat } \\
\text { Layak }\end{array}$ \\
\hline $\begin{array}{l}X_{i}+0.60 S b_{i} \\
<x \\
\leq X_{i}+1.80 S b_{i}\end{array}$ & $3.4<x \leq 4.21$ & Layak \\
\hline $\begin{array}{l}X_{i}-0.60 S b_{i} \\
<x \\
\leq X_{i}+0.60 S b_{i}\end{array}$ & $2.60<x \leq 3.40$ & $\begin{array}{l}\text { Cukup } \\
\text { Layak }\end{array}$ \\
\hline $\begin{array}{l}X_{i}-1.80 S b_{i} \\
<x \\
\leq X_{i}-0.60 S b_{i}\end{array}$ & $1.79<x \leq 2.60$ & $\begin{array}{l}\text { Kurang } \\
\text { Layak }\end{array}$ \\
\hline $\begin{array}{l}x \\
\leq X_{i}-1.80 S b_{i}\end{array}$ & $x \leq 1.79$ & $\begin{array}{l}\text { Sangat } \\
\text { Kurang } \\
\text { Layak }\end{array}$ \\
\hline
\end{tabular}

Dimana:

$x \quad$ :Skor rata-rata kuisoner

Rerata Ideal $\left(X_{i}\right)$ :

$$
\begin{aligned}
& \frac{1}{2}(\text { skor } \max +\text { skor } \min ) \\
& X_{i}=\frac{1}{2}(5+1) \\
& X i=3
\end{aligned}
$$

Simpangan baku ideal:

$$
\begin{aligned}
& \left(S b_{i}\right)=\frac{1}{6}(\text { skor max }- \text { skor } \min ) \\
& S b_{i}=\frac{1}{6}(5-1) \\
& S b_{i}=0.67
\end{aligned}
$$

\section{HASIL PENELITIAN DAN PEMBAHASAN}

\subsection{Hasil Penelitian}

\subsubsection{Deskripsi Studi Pendahuluan (Analisis)}

a. SLB Negeri Kota Gorontalo memiliki ruang laboratorium yang menyediakan beberapa perlengkapan multimedia seperti LCD Proyektor, Personal Computer, Speaker yang belum dimanfaatkan secara maksimal dalam proses pembelajaran khususnya dalam mata pelajaran Bahasa Inggris. Ruang laboratorium saat ini yang tersedia biasanya digunakan dalam proses pembelajaran berhubungan dengan mata pelajaran TIK (Teknologi Informasi dan Komunikasi) saja. Oleh karena itu, sebagaimana informasi yang diperoleh bahwa pembelajaran Bahasa Inggris belum sepenuhnya memanfaatkan fasilitas dan media berbasis ICT.

b. Guru mata pelajaran Bahasa Inggris masih banyak mengandalkan buku teks dan papan tulis untuk mengajarkan mata pelajaran Bahasa Inggris khususnya di kelas tunarungu.

c. Salah satu kendala lain yang ditemui dalam pengajaran Bahasa Inggris bagi anak luar biasa khususnya tunarungu yakni peserta didik menunjukan kemauan dan kemampuan pemahaman yang baik dalam pembelajaran Bahasa Inggris, namun pada dasarnya diperlukan strategi yang baik untuk guru agar dapat memilih dan mengidentifikasi solusi yang tepat terhadap kesulitan yang dimiliki oleh masing-masing peserta didik tersebut.

d.Pembelajaran bahasa Inggris di kelas tunarungu saat ini diimplementasikan dengan mengajak peserta didik 
belajar secara konventional di dalam kelas dan terkadang mengandalkan suasana kontekstual dengan menggunakan media realia yang dipersiapkan oleh guru pengajar Bahasa Inggris. Namun beberapa kendala yang ditemui terkait hal ini adalah guru memiliki keterbatasan waktu untuk merancang suatu media realia, serta harus menyediakan media tersebut pada saat proses pembelajaran berlangsung. Disisi lain guru dihadapkan pada kondisi dimana proses assessment secara individual yang dilakukan pada saat proses pembelajaran berlangsung harus dijalankan untuk mengetahui kebutuhan belajar peserta didik tunarungu masingmasing. Konsekuensinya adalah guru terfokus dalam suasana pembelajaran yang menekankan pada peningkatan kognitif peserta didik, sehingga sedikit mengabaikan hal-hal yang berhubungan dengan pembelajaran yang melibatkan afektif dan psikomotor peserta didik.

e. Proses evaluasi keberhasilan pembelajaran Bahasa Inggris dilakukan oleh guru pengajar dengan cara mengeneralisasi secara langsung atau melihat secara keseluruhan pemahaman peserta didik, namun dengan menitikberatkan penilaian evaluasi individual sesuai dengan format yang telah disedikan oleh pihak sekolah. Hal ini menyebabkan guru sering mengalami kesulitan dalam mengevaluasi para peserta didik secara satu per satu. Sedangkan alokasi waktu yang tersedia untuk mengajar mata pelajaran bahasa Inggris terbatas. Dengan demikian, hasil evaluasi tidak dapat secara komprehensif diperoleh oleh guru yang bersangkutan.

f. Dalam proses transfer materi pembelajaran bagi peserta didik tunarungu, guru dihadapkan pada beberapa kondisi dan penyesuaian strategi pembelajaran misalnya, waktu, fasilitas, dan kemampuan peserta didik untuk memahami dan menyerap materi yang diajarkan menggunakan bahasa Asing yakni Bahasa Inggris. Karena disisi lain peserta didik tunarungu juga masih mengalami keterbatasan dalam memahami kosakata Bahasa Indonesia.

g. Responden menyatakan diperlukan adanya pengembangan media pembelajaran yang dapat secara efektif dan efisien membantu proses pelaksanaan pembelajaran Bahasa Inggris. Sehingga melalui pengembangan media ini mampu memberikan kesempatan kepada peserta didik tunarungu untuk mempelajari materi secara mandiri, membantu guru untuk mengevaluasi sesuai dengan alokasi waktu yang ditargetkan, menumbuhkan minat dan motivasi peserta didik tunarungu untuk mempelajari bahasa Inggris dengan antusias dikarenakan desain media yang dirancang melibatkan unsur tidak hanya secara kognitif melainkan juga afektif dan psikomotor para peserta didik.

Mempertimbangkan beberapa data hasil penelitian yang diperoleh melalui hasil observasi dan wawancara secara langsung di lapangan, maka tim peneliti bermaksud membuat media pembelajaran bahasa Inggris untuk peserta didik kelas tunarungu dalam mempelajari kosakata Bahasa Inggris sesuai dengan topik yang ada di lingkungan sekitar peserta didik yakni di sekolah, di rumah dan di tempat bermain sesuai dengan analisis kompetensi inti yang diharapkan bagi peserta didik tunarungu.

\subsubsection{Perencanaan Desain}

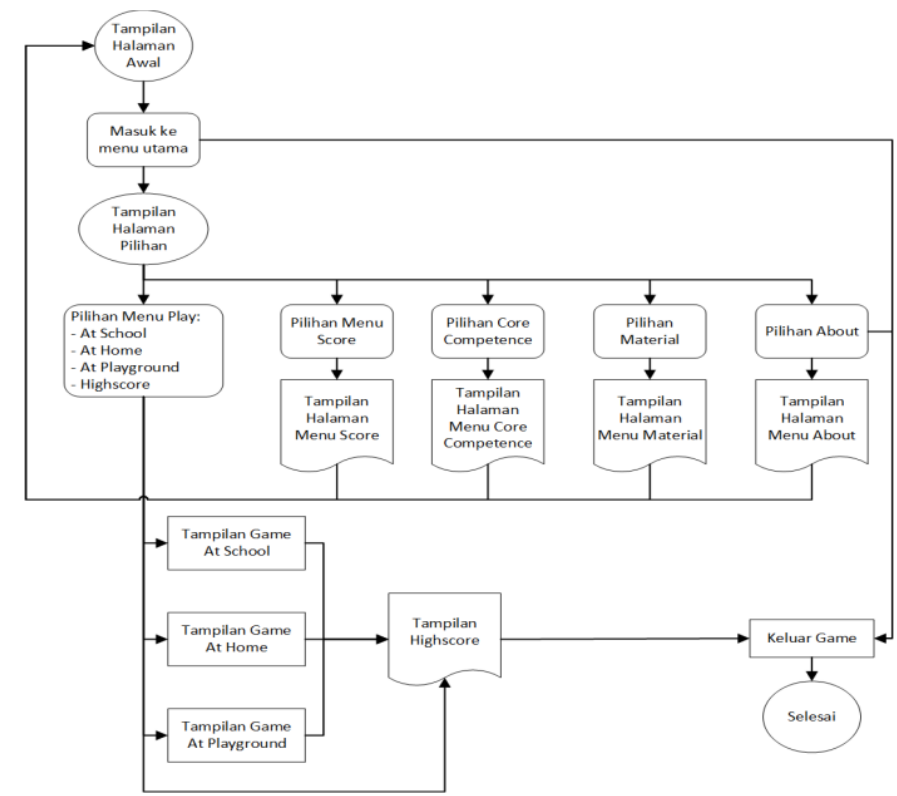

Gambar 1. Perencanan Desain Storyboard

\subsubsection{Pengembangan Desain}

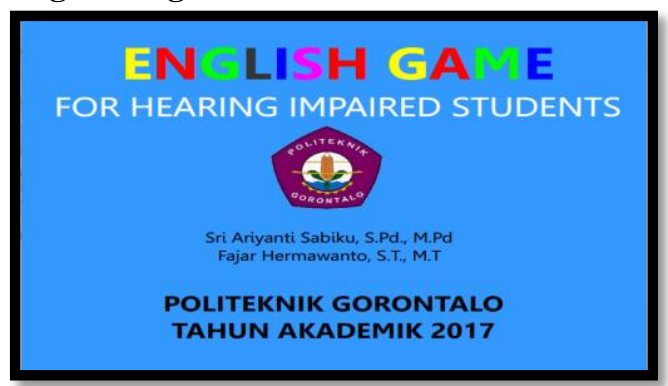

Gambar 2. Hasil Implementasi Halaman Awal

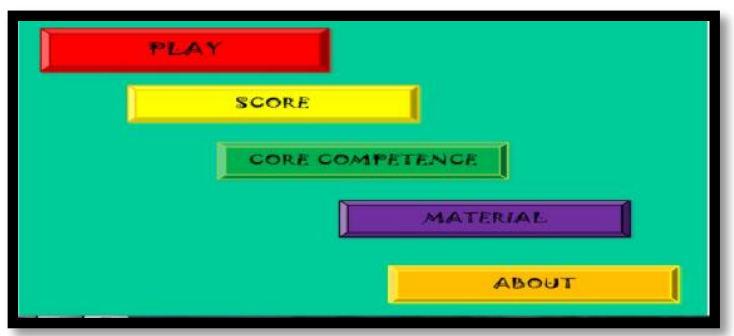

Gambar 3. Hasil Implementasi Halaman Pengantar

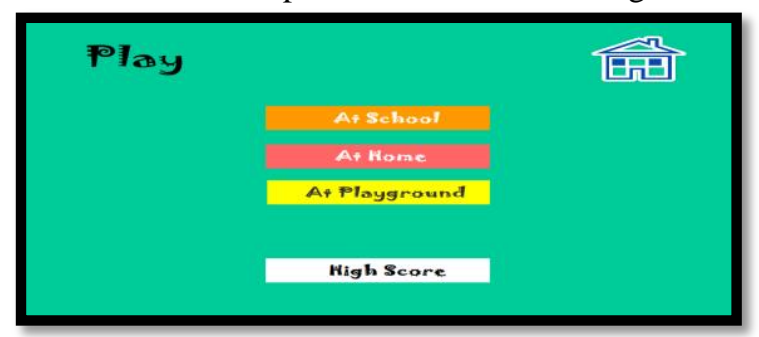

Gambar 4.Hasil Implementasi Halaman Menu "Play"

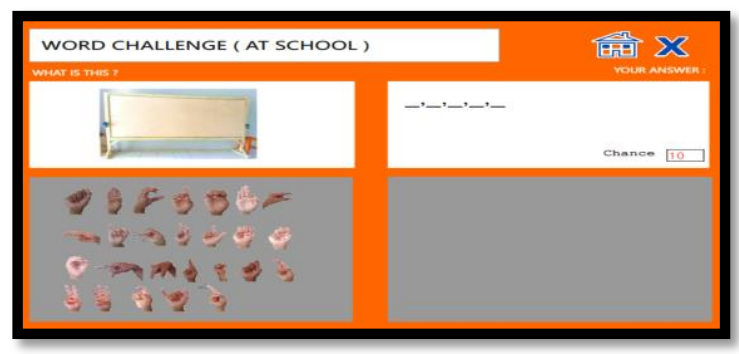

Gambar 5. Hasil Implementasi Game Word Challenge - At School (Abjad dengan Simbol Jari) 


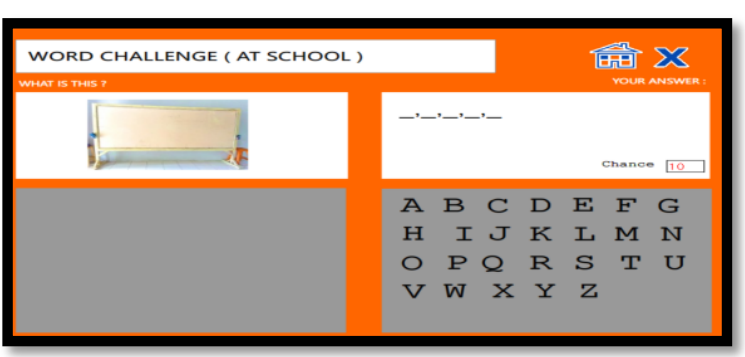

Gambar 6. Hasil Implementasi Game Word Challenge - At School (Abjad dengan Simbol Huruf)

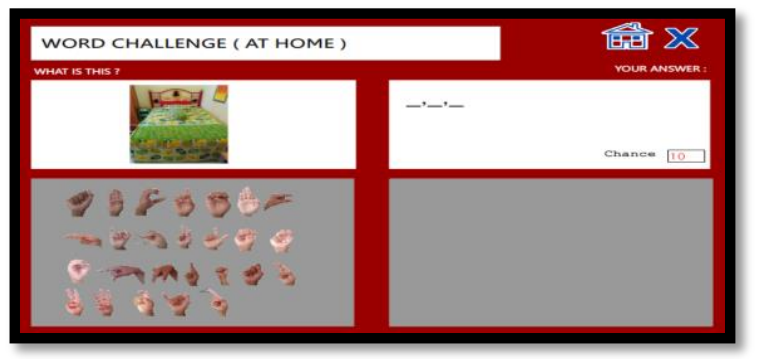

Gambar 7. Hasil Implementasi Game Word Challenge - At Home (Abjad dengan Simbol Jari)

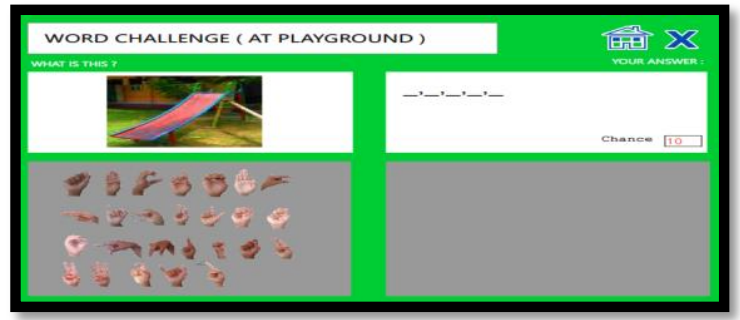

Gambar 9. Hasil Implementasi Game Word Challenge - At Playground (Abjad dengan Simbol Jari)

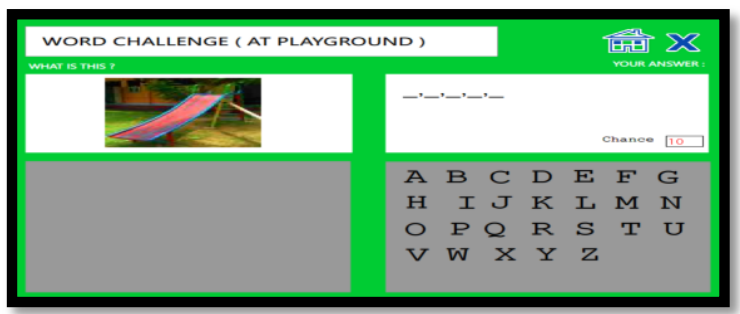

Gambar 10. Hasil Implementasi Game Word Challenge - At Playground (Abjad dengan Simbol Huruf)

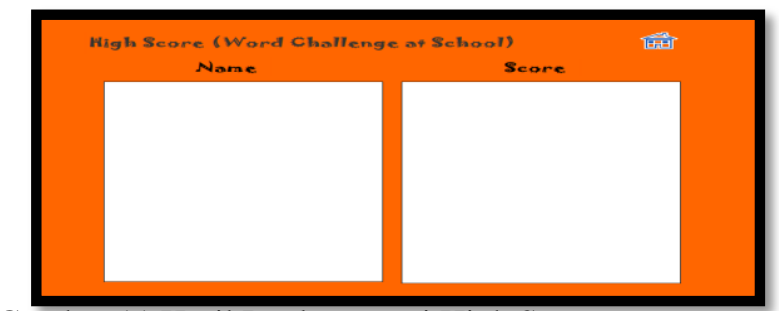

Gambar 11.Hasil Implementasi High Score (Urutan SkorPerolehan)

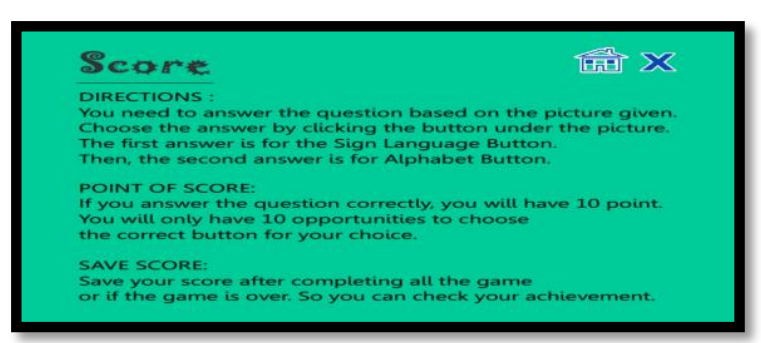

Gambar 12. Hasil Implementasi Halaman Menu "Score"
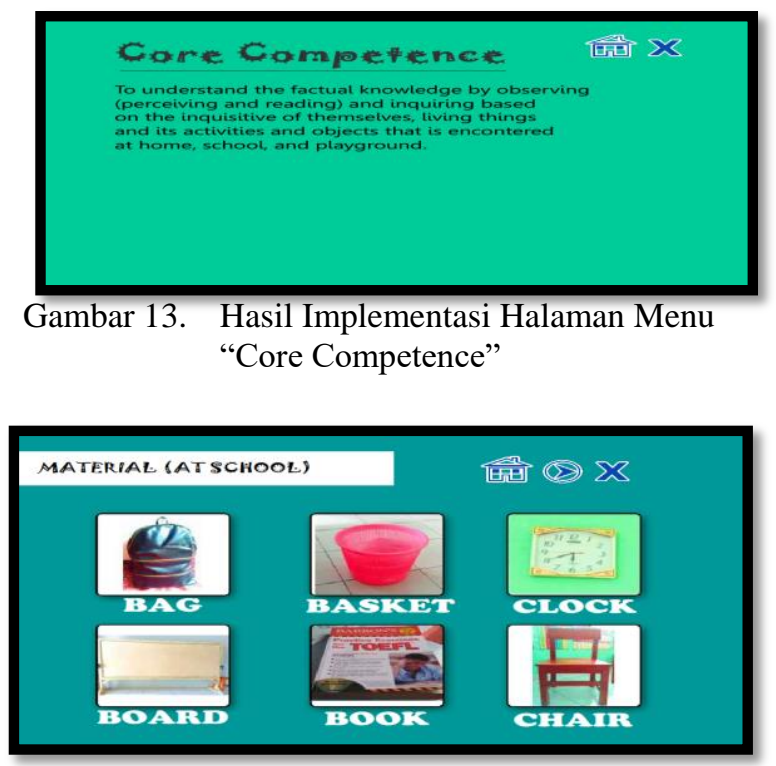

Gambar 14. Hasil Implementasi Halaman Menu "Material"

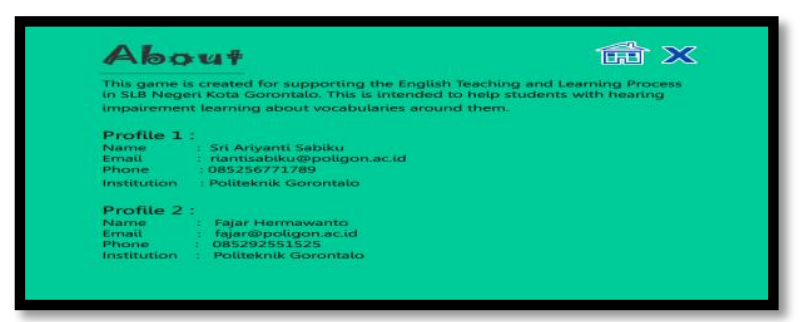

Gambar 15. Hasil Implementasi Halaman Menu "About"

\subsubsection{Hasil Validasi dan Revisi Produk}

\section{- Validasi Ahli Media dan Revisi Produk}

Validasi media pembelajaran Aplikasi English Game for Hearing Impaired Students dilakukan oleh tiga orang dosen. Tiga orang dosen tersebut merupakan ahli di bidang media dengan latar belakang kejuruan yakni 2 orang dosen dari jurusan Teknik Informatika dan 1 orang dosen dari jurusan Sistem Informasi. 3 orang ahli media mengisi angket untuk memberikan penilaian mengenai media dengan penilaian sangat layak sampai sangat tidak layak, serta memberikan komentar, saran dan masukan atas perbaikan media pembelajaran yang telah dirancang oleh tim peneliti. Aspek-aspek yang dinilai dalam pengujian kelayakan media oleh ahli media meliputi: aspek navigasi, aspek tampilan, aspek tulisan, dan aspek kemudahan.Terdapat beberapa kekurangan yang telah direvisi oleh tim peneliti dan perbaikan-perbaikan yang disarankan oleh ahli media diantarannya adalah:

a) Media pembelajaran perlu dibuat lebih interaktif.

b) Tampilan background pada media pembelajaran perlu di desain dengan lebih menarik.

c) Jumlah soal latihan kosakata ditambahkan agar lebih variatif.

d) Jumlah materi perlu ditambahkan pada media pembelajaran.

e) Sound tidak diperlukan pada media pembelajaran.

f) Ditambahkan penjelasan mengenai aturan main.

Rata-rata penilaian dari ahli media terkait media pembelajaran menunjukan bahwa Aplikasi English Game for Hearing Impaired Students Berbasis Komputer Sebagai Media Pembelajaran dalam Meningkatkan Kosakata Bahasa

PENGEMBANGAN APLIKASI ENGLISH GAME 
Inggris di SLB Negeri Kota Gorontalo adalah sebagai berikut:

Kuisioner ahli media berisi 19 pertanyaan yang diisi oleh tiga orang ahli media, sehingga skor yang mungkin diperoleh berkisar dalam range 57 (1x19x3) sampai dengan 285 (kriterium $=5 \times 19 \times 3)$. Setelah dihitung berdasarkan langkah yang dijelaskan pada bagian 2.5.2, diperoleh interval koefisien sebesar 57. Secara keseluruhan, hasil penilaian ahli media disajikan pada tabel dan gambar dibawah ini

Tabel 3: Hasil Penilaian Ahli Media

\begin{tabular}{|c|c|c|c|}
\hline $\begin{array}{l}\text { Tingkat } \\
\text { Penilaian }\end{array}$ & Jumlah & Nilai & $\begin{array}{l}\text { Skor } \\
\text { (Jml Jawaban * Nilai) }\end{array}$ \\
\hline SS & 27 & 5 & 135 \\
\hline S & 28 & 4 & 112 \\
\hline $\mathrm{R}$ & 0 & 3 & 0 \\
\hline TS & 2 & 2 & 4 \\
\hline STS & 0 & 1 & 0 \\
\hline Total & 57 & & 251 \\
\hline
\end{tabular}

Skor angket adalah 251, yang berada diantara Setuju (S) dan Sangat Setuju (SS). Nilai maksimum skor (kriterium) adalah 285, sehingga, secara keseluruhan, tingkat persetujuan ahli media terhadap angket adalah $\frac{251}{285}=$ $88.07 \%$. Ini bisa digambarkan dalam kontinum sebagai berikut:

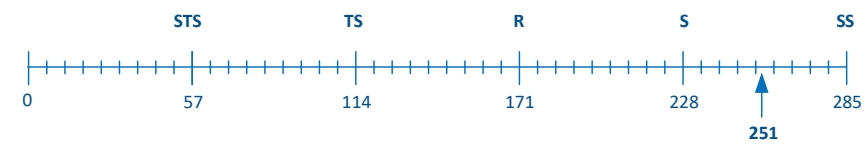

Secara rinci maka dapat dijabarkan hasil akhir validasi ahli media terkait aspek penilaian dalam media pembelajaran yang telah direvisi dan diperbaiki oleh tim peneliti sebelum diujicobakan kepada responden adalah sebagai berikut:

Tabel 4: Hasil Akhir Validasi Ahli Media

$\begin{array}{llll}\text { No } & \begin{array}{l}\text { Aspek } \\ \text { Penilaian }\end{array} & \text { Rata-Rata } & \text { Kategori } \\ 1 & \text { Navigasi } & 4.333 & \text { Sangat Layak } \\ 2 & \text { Tampilan } & 4 & \text { Layak } \\ 3 & \text { Tulisan } & 4.8 & \text { Sangat Layak } \\ 4 & \text { Kemudahan } & 4.533 & \text { Sangat Layak } \\ \text { Total } & & 4.403 & \text { Sangat Layak }\end{array}$

\section{- Validasi Ahli Materi dan Revisi Produk}

Data validasi ahli materi digunakan untuk mengetahui keselurahan materi yang dituangkan dalam media pembelajaran. Validasi ahli materi diambil dari tiga orang guru di SLB Negeri Kota Gorontalo. Ahli materi mengisi angket yang menggambarkan penilaian ahli materi dengan kategori di mulai dari sangat layak sampai dengan sangat tidak layak. Ahli materi juga memberikan komentar, saran dan perbaikan terkait materi pada media pembelajaran. Aspek-aspek yang dinilai dalam pengujian kelayakan materi oleh ahli materi meliputi aspek pembelajaran dan aspek materi. Beberapa komentar, saran dan perbaikan dari ahli materi antara lain sebagai berikut:

a. Materi yang telah dikategorikan berdasarkan topik sebaiknya lebih dipilih sesuai dengan benda-benda yang terdekat, familiar dan sering ditemui oleh peserta didik sekolah luar biasa.

b. Konten materi kosakata lebih ditambahkan daripada soal latihan sehingga guru dan peserta didik dapat menggunakan aplikasi tersebut sebagai alternatif media pembelajaran mandiri, tidak hanya sekedar soal latihan atau evaluasi.

c. Materi mengenai pilihan abjad dengan simboljari diurutkan atau ditempatkan sesuai dengan abjad dengan simbol huruf agar dapat mudah dipelajari khususnya untuk guru yang tidak memiliki latar belakang khusus di bidang pendidikan luar biasa bagi anak tunarungu (paham mengenai sign language).

d.Memperbaiki atau meninjau kembali tata tulis dan ejaan kosakata Bahasa Inggris dalam media pembelajaran.

Sebagaimana data hasil validasi ahli materi yang diperoleh, maka kekurangan dan saran perbaikan telah dilakukan dan diperbaiki oleh peneliti.

Rata-rata penilaian ahli materi menunjukan bahwa Aplikasi English Game for Hearing Impaired Students Berbasis Komputer Sebagai Media Pembelajaran Dalam Meningkatkan Kosakata Bahasa Inggris di SLB Negeri Kota Gorontalo adalah sebagai berikut:

Kuisioner ahli materi berisi 20 pertanyaan yang diisi oleh tiga orang ahli materi, sehingga skor yang mungkin diperoleh adalah minimum $60(1 \times 20 \times 3)$ dan maksimum 300 (5x20x3), sehingga interval nilainya adalah $240(300-60)$. Seperti perhitungan sebelumnya, 5 kategori penilaian menghasilkan interval nilai sebesar $25 \%$. Maka, interval koefisien adalah $60(240 * 25 \%)$. Secara keseluruhan, hasil penilaian ahli materi disajikan pada tabel dan gambar dibawah ini:

Tabel 5. Hasil Penilaian Ahli Materi

$\begin{array}{llll}\begin{array}{l}\text { Tingkat } \\ \text { Penilaian }\end{array} & \begin{array}{l}\text { Jumlah } \\ \text { Jawaban }\end{array} & \text { Nilai } & \begin{array}{l}\text { Skor } \\ \text { (Jml Jawaban * } \\ \text { Nilai) }\end{array} \\ \text { SS } & 30 & 5 & 150 \\ \text { S } & 30 & 4 & 120 \\ \text { R } & 0 & 3 & 0 \\ \text { TS } & 0 & 2 & 0 \\ \text { STS } & 0 & 1 & 0 \\ \text { Total } & 60 & & 270\end{array}$

Skor angket adalah 270, yang berada diantara Setuju (S) dan Sangat Setuju (SS). Nilai maksimum skor (kriterium) adalah 300, sehingga, secara keseluruhan, tingkat persetujuan peserta didik terhadap angket adalah $\frac{270}{300}=90 \%$. Ini bisa digambarkan dalam kontinum sebagai berikut:

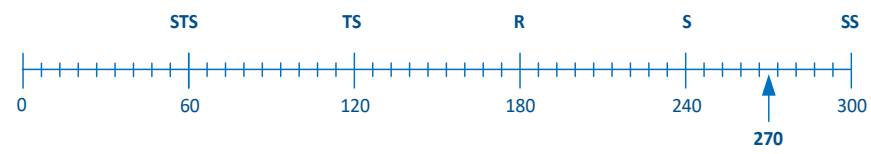

Secara rinci maka dapat dijabarkan hasil akhir validasi ahli materi terkait aspek - aspek penilaian materi dalam media pembelajaran yang telah direvisi dan diperbaiki oleh tim peneliti sebelum diujicobakan kepada responden yakni: Tabel 6. Hasil Akhir Validasi Ahli Materi

$\begin{array}{llll}\text { No } & \text { Aspek Penilaian } & \text { Rata-Rata } & \text { Kategori } \\ 1 \quad \text { Pembelajaran } & 4.73 & \text { Sangat Layak } \\ 2 \quad \text { Materi } & 4.26 & \text { Sangat Layak } \\ \text { Total } & 4.5 & \text { Sangat Layak }\end{array}$

\section{- Hasil Ujicoba Pengguna}

Uji coba pengguna media dilakukan oleh 9 orang peserta didik tuna rungu tingkat SMP di SLB Negeri Kota Gorontalo. Secara garis besar, ada empat aspek yang diniliai pada angket. Keempat aspek tersebut adalah (1) motivasi siswa, (2) kemudahan penggunaan aplikasi, (3) kemenarikan aplikasi, dan (4) kemanfaatan aplikasi. Berikut ini akan dijabarkan metode analisis yang digunakan pada 
penelitian ini, diikuti dengan analisis data angket berdasarkan keempat aspek tersebut.

Secara rinci maka dapat dijabarkan hasil akhir uji coba pengguna terkait penilaian terhadap media pembelajaran adalah sebagai berikut:

Tabel 7. Hasil Akhir Uji Coba Pengguna

\begin{tabular}{llll} 
No & Aspek & Rata-Rata & Kategori \\
1 & Motivasi & 4.259 & Sangat Layak \\
2 & Kemudahan & 4.611 & Sangat Layak \\
3 & Kemenarikan & 4.740 & Sangat Layak \\
4 & Kemanfaatan & 4.556 & Sangat Layak \\
\multicolumn{2}{l}{ Total } & 4.533 & Sangat Layak
\end{tabular}

Dapat dilihat dalam tabel diatas bahwa penilaian pengguna yakni peserta didik tunarungu terhadap media pembelajaran yang dirancang oleh tim peneliti sangat layak dengan rata-rata $\mathbf{=} \mathbf{4 . 5 3 3}$.

\subsubsection{Hasil Evaluasi Penguasaan Kosakata Bahasa Inggris}

Berdasarkan hasil penelitiandapat diperoleh perbandingan evaluasi hasil penguasaan kosakata Bahasa Inggris peserta didik tunarungu tanpa menggunakan aplikasi dan dengan menggunakan aplikasi sebagai berikut:

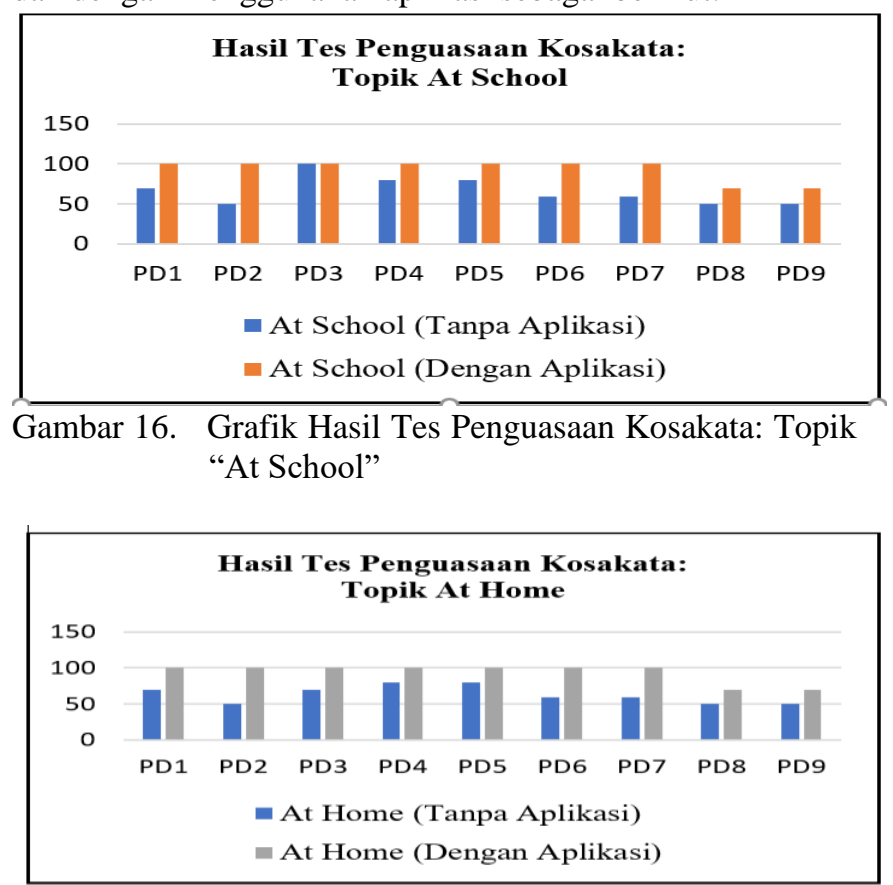

Gambar 17. Grafik Hasil Tes Penguasaan Kosakata: Topik "At Home"

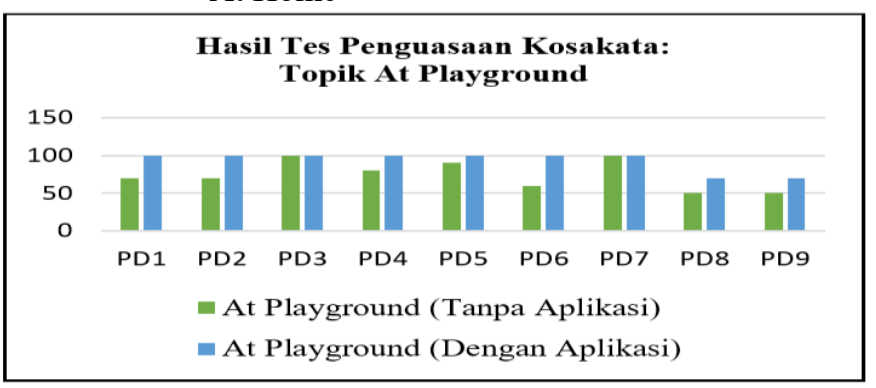

Gambar 18. Grafik Hasil Tes Penguasaan Kosakata: Topik

"At Playground"

\subsection{PEMBAHASAN}

Seiring dengan kemajuan zaman dan teknologi, pembaharuan media pembelajaran dalam dunia pendidikan sangatlah penting. Pembaharuan media pembelajaran akan memberikan pengaruh terhadap pencapaian dan kualitas hasil pembelajaran. Pemilihanatau perancangan media dengan tepat dan sesuai kondisi/situasi untuk suatu pembelajaran tentulah mendukung terlaksananya capaian hasil pembelajaran yang telah ditargetkan. Berbagai jenis media pembelajaran dapat menjadi alternatif bagi guru pengajar baik yang berasal dari hasil rancangan dan kreatifitas guru pengajar itu sendiri secara manual ataupun berbasis teknologi.

Beberapa permasalahan muncul sebagai kendala dalam menciptakan suatu media pembelajaran yang tepat berdasarkan situasi dan kebutuhan peserta didik adalah sarana dan prasarana penunjang yang kurang mendukung untuk disediakan oleh pihak sekolah. Sehingga kendala tersebut berdampak pada berkurangnya juga kreatifitas guru dalam merancang suatu media yang baik sesuai dengan target siapa, kapan dan dimana media ini akan diimplementasikan.

Sesuai dengan hasil observasi dan wawancara yang dilakukan dalam penelitian ini bahwa proses pembelajaran yang dilaksanakan di lokasi penelitian yakni SLB Negeri Kota Gorontalo pada umumnya masih menggunakan media pembelajaran secara conventional/manual seperti flashcards hasil rancangan guru, buku teks, papan tulis. Media ini dianggap menjadi langkah yang tepat dalam mengajar peserta didik berkebutuhan khusus seperti peserta didik tunarungu. Sistem pembelajaran dengan menggunakan media-media seperti ini terkadang berbenturan dengan pengelolaan waktu dan antusias peserta didik dalam pembelajaran. Fasilitas sarana dan prasarana berbasis teknologi yang mampu memberikan pilihan secara efisien sejauh ini masih belum secara maksimal diimplementasikan.

Dengan demikian, menanggapi beberapa permasalahan yang ditemui pada saat observasi dan wawancara, maka tim peneliti mengembangkan media game pembelajaran berbasis komputer yakni dalam bentuk aplikasi Macromedia Flash 8. Putra dalam Anandhita (2014) menjabarkan bahwa terdapat 5 klasifikasi istilah game yakni, (1) Board Game, (2) Card Games, (3) Athletic Games, (4) Children Games, (5) Computer Games. Sedangkan, Heinich, et al dalam buku Pribadi \& Putri (2001) menambahkan terdapat enam bentuk interaksi yang dapat diaplikasikan dalam merancang sebuah media pembelajaran yang berbasis komputer, berupa: (1) Praktek dan latihan (drill and Practice), (2) Tutorial (3) Permainan (Games), (4) Simulasi (Simulation), (5) Penemuan (Discovery), (6) Pemecahan Masalah (Problem Solving).

Pada penelitian ini, game yang dipilih oleh tim peneliti untuk dikembangkan merupakan jenis Computer Game yang dilengkapi dengan materi pembelajaran kosakata dan permainan-permainan tebak gambar. Game ini mampu menjadi alternatif media pembelajaran baik untuk mengenalkan kosakata bahasa Inggris kepada peserta didik tunarungu sekaligus dilengkapi dengan soal latihan yang ditargetkan mampu memberikan kesempatan kepada peserta didik dalam mengeja dan mengingat setiap kosakata yang ditampikan berdasarkan situasi yang ditemui oleh peserta didik sehari-harinya.

Selain itu berdasarkan hasil observasi dan wawancara, sistem pembelajaran pada mata pelajaran Bahasa Inggris di SLB Negeri Kota Gorontalo Kelas Tunarungu menekankan pada guru sebagai pengendali utama di dalam kelas atau dengan kata lain teacher-centered. Kondisi ini semakin memicu berkurangnya perhatian dan rasa antusias peserta didik tunarungu dalam pembelajaran. Aspek yang dikedepankan dalam sistem pembelajaran bahasa Inggris dilihat masih berlandaskan pada fokus aspek kognitif peserta didik tunarungu, sehingga kadang kala mengabaikan beberapa hal seperti psikomotor dan afektif. 
Dengan adanya media pembelajaran berbentuk game berbasis komputer, pembelajaran menjadi lebih menarik dan peserta didik merasa dilibatkan secara langsung untuk turut aktif dalam mempraktekkan secara langsung bahan kosakata yang dituangkan dalam aplikasi tersebut. Tampilan yang menyediakan abjad dalam simbol jari maupun abjad dalam simbol huruf (alfabet) tidak hanya membantu peserta didik tunarungu dalam memahami setiap ejaan huruf pada masing-masing kosakata, melainkan memberikan kesempatan untuk dapat menilai kemampuan individual masing-masing dan diskusi antara peserta didik secara aktif. Skor yang dapat dilihat secara langsung dalam media ini telah membantu peserta didik tunarungu menumbuhkembangkan minat dan motivasi dalam mempelajari setiap ejaan kosakata tersebut di setiap proses pembelajaran berlangsung.

\section{KESIMPULAN DAN SARAN}

\subsection{Kesimpulan}

Berdasarkan hasil penelitian dan pembahasan dapat disimpulkan sebagai berikut:

a. Media pembelajaran yang dihasilkan yakni berupa Aplikasi English Game for Hearing Impaired Students Berbasis Komputer. Aplikasi ini dibuat menjadi aplikasi portable dengan format exe yang kemudian dikemas dalam bentuk kepingan Compact Disk.

b.Konten materi dan soal latihan yang dituangkan dalam media pembelajaran ini meliputi benda-benda yang dapat dijumpai di lingkungan sekitar peserta didik tunarungu dengan 3 topik pilihan kosakata berupa living things, its activities dan object yang dijumpai di sekolah, di rumah, serta di tempat bermain. Keseluruhan kosakata dan gambar disesuaikan dengan kompetensi inti dalam silabus, buku teks yang digunakan oleh guru dan peserta didik tunarungu serta analisis kebutuhan masing-masing peserta didik secara individual yang berlaku untuk mendukung kegiatan belajar mengajar mata pelajaran bahasa Inggris kelas tunarungu di SLB Negeri Kota Gorontalo.

c.Soal latihan yang ditampilkan dalam media pembelajaran di lengkapi dengan real picture, pilihan abjad dengan symbol jari(sign language) dan abjad dengan simbol huruf (alphabets) bagi peserta didik tunarungu, serta bantuan jumlah kosakata yang seharusnya ditebak dengan durasi atau batas koreksi kesalahan untuk membantu peserta didik tunarungu memahami pengetahuan faktual dengan cara mengamati [melihat, membaca] dan menanya berdasarkan rasa ingin tahu tentang dirinya, makhluk ciptaan Tuhan dan kegiatannya, dan benda-benda yang dijumpainya di rumah di sekolah, dan tempat bermain.

d. Data hasil validasi ahli media dan ahli materi menyimpulkan bahwa Aplikasi English Game for Hearing Impaired Students Berbasis Komputer layak diujicoba dilapangan dengan revisi. e. Penelitian ini membuktikan adanya peningkatan penguasaan kosakata Bahasa Inggris yang dapat tergambarkan melalui perbandingan masing-masing skor perolehan tes kosakata peserta didik tunarungu yang menggunakan aplikasi dibandingkan tanpa menggunakan aplikasi dalam proses pembelajaran.

\subsection{Saran}

\section{a. Kepada Pihak Sekolah}

SLB Negeri Kota Gorontalo sebaiknya dapat memberikan pelatihan kepada guru untuk dapat membuat pembelajaran berbasis multimedia sehingga pembelajaran dapat menjadi lebih menarik, variatif serta kreatif. Sekolah dapat menambah dan memaksimalkan pemanfaatan fasilitas yang disediakan di Sekolah Luar Biasa untuk meningkatkan keefektifan proses pembelajaran di kelas bagi peserta didik berkebutuhan khusus.

\section{b. Guru Mata Pelajaran Bahasa Inggris}

Kemajuan teknologi semakin lama semakin berkembang pesat. Kebutuhan akan informasi di era globalisasi menjadi tuntutan agar guru dan peserta didik memiliki keterampilan yang serba bisa dalam penggunaan teknologi. Oleh karena itu dengan adanya penggunaan media pembelajaran yang interaktif dan berbasis teknologi mampu membantu meningkatkan kemampuan dan menarik minat/motivasi belajar peserta didik khususnya peserta didik tunarungu. Selain itu diharapkan bagi guru mampu memiliki keahlian untuk mampu menciptakan atau mengembangkan media pembelajaran yang mampu menumbuhkan suasana menyenangkan dan mampu menunjang kebutuhan para peserta didik tersebut.

\section{c. Peneliti/Pengembang}

Peneliti/Pengembang sebaiknya dapat memproduksi produk secara massal dan dapat digunakan secara luas oleh pengguna sehingga seharusnya pengembang melanjutkan penelitian sampai pada tahap akhir. Kualitas aplikasi yang dihasilkan seharusnya dapat ditingkatkan dan disempurnakan untuk mengurangi kelemahan dan kekurangan dari produk yang telah dihasilkan. Selain itu, disarankan dalam penelitian selanjutnya dapat melakukan ujicoba pengguna secara luas dengan mengambil subjek atau responden yang lebih banyak.

\section{DAFTAR PUSTAKA}

Anandhita, Nur Arif. (2014). Pengembangan media games berbasis unity $3 D$ sebagai media evaluasi pembelajaran musik di smpnegeri 4 purworejo. Skripsi pada Jurusan Pendidikan Seni Musik UNY. Yogyakarta: tidak diterbitkan

Dewi, Ghea. (2012). Pengembangan game edukasi pengenalan nama hewan dalam bahasa inggris sebagai media pembelajaran siswa sdberbasis macromedia flash. Skripsi pada Program Studi Pendidikan Teknik Informatika UNY. Yogyakarta: tidak diterbitkan

Harahap, Nazruddin Safaat \&Sari, Oktariani(2016).Rancang bangun aplikasi pembelajaran bahasa inggris berbasis kinect. Jurnal CoreIT, 21-28, Program Studi Teknik Informatika, Fakultas Sains dan Teknologi, UIN Sultan Kasim Riau, Pekanbaru

Pribadi, B.A \& Putri, D.P. (2001). Ragam media dalam pembelajaran.Jakarta: Pusat Antar Universitas Untuk Peningkatan dan Pengembangan Aktivitas Instruksional Universitas Terbuka

Somantri, S. (2012). Psikologi anak luar biasa. Bandung. PT. Refika Aditama

Sugiyono. (2012). Metode penelitian kombinasi (mixed methods).Bandung. Alfabeta

Sukardjo. (2005). Evaluasi pembelajaran. Diktat Mata Kuliah Evaluasi Pembelajaran. Program Studi TP PPs UNY. Tidak diterbitkan. 


\section{PEDOMAN PENULISAN JURNAL JTII}

1. NASKAH dapat ditulis dalam Bahasa Indonesia atau Bahasa Inggris, diketik diatas kertas ukuran A4 dengan software Microsoft Word jarak 2 spasi maksimum 6 Halaman, menggunakan huruf Time News Roman ukuran 10 pts untuk isi artikel dan ukuran 10 pts untuk ringkasan dan abstrak, dan dikrim kepada redaksi dalam bentuk hard copy dan soft copy sebanyak 2 rangkap.

\section{SISTEMATIKA ARTIKEL}

a. Judul harus menggambarkan isi pokok tulisan secara ringkas, jelas, dan tidak lebih dari $20 \mathrm{kata}$, ditulis dalam bahasa Indonesia dan bahasa ingris dengan huruf Arial Narrow 10 pts. Untuk naskah dalam bahasa Indonesia ditulis dengan huruf BESAR SEMUA, TEBAL, DITENGAH disertai dengan terjemahan bahasa ingris yang ditulis dengan huruf Besar Kecil, Tebal-Miring. Demikian juga sebaliknya untuk naskah yang ditulis dalam bahasa ingris.

b. Nama Penulis ditulis tanpa gelar akademik dengan mencantumkan tempat kerja di bawah judul artikel dengan huruf Time News Roman 10 pts.

c. Ringkasan dan Abstrak paling banyak 250 kata. Naskah yang ditulis dalam bahasa Indonesia, ringkasannya ditulis dalam bahasa Indonesia dan Abstract dalam bahasa ingris, demikian juga sebaliknya untuk naskah yang ditulis dalam Bahasa Inggris dan dilengkapi dengan kata kunci.

d. Pendahuluan berisi masalah yang mendorong penyelenggaraan penelitian, sedikit tinjauan pustaka yang terkait dengan penelitian, rumusan masalah, dan tujuan penelitian.

e. Metode penelitian menjelaskan tentang jenis, disain, teknik pengumpulan data, dan teknik analisis data penelitian.

f. Hasil dan Pembahasan berisi tentang temuan penelitian dan bila perlu dapat dijelaskan dengan table, grafik, diagram, ilustrasi, lukisan, foto yang ditulis secara singkat dan jelas dalam Bahasa Indonesia dan Bahasa Inggris. Nama tabel ditulis dibagian atas tabel, nama grafik/diagram/ilustrasi/gambar/foto ditulis dibagian bawah, foto/ gambar berwarna dengan ukuran kartu pos.

\section{Contoh penulisan tabel}

Tabel 1. Disain Penelitian

Table 1. Research Design

g. Kesimpulan memuat hasil/temuan penelitian sebagai jawaban terhadap masalah penelitian

h. Daftar pustaka memuat nama pengarang yang diurutkan secara alfabetis berdasarkan marga, tahun penerbitan, judul terbitan atau majalah, volume, nomor serta halaman (untuk terbitan), nomor seri dan kota penerbitan. 